\title{
EE-1
}

PAPER - OPEN ACCESS

Keterkaitan antara Aspek Lingkungan pada Pariwisata Berkelanjutan terhadap Distinctiveness (Studi Kasus Kawasan Geopark Kaldera Toba)

\author{
Author \\ DOI $\quad: 10.32734 /$ ee.v3i1.855 \\ Electronic ISSN $\quad: 2654-704 \mathrm{X}$ \\ Print ISSN : :2654-7031
}

Volume 3 Issue 1 - 2020 TALENTA Conference Series: Energy \& Engineering (EE)

This work is licensed under a Creative Commons Attribution-NoDerivatives 4.0 International License.

Published under licence by TALENTA Publisher, Universitas Sumatera Utara 


\title{
jibli (4) TALENTA Conference Series
}

Available online at https://talentaconfseries.usu.ac.id/ee

\section{Keterkaitan antara Aspek Lingkungan pada Pariwisata Berkelanjutan terhadap Distinctiveness (Studi Kasus Kawasan Geopark Kaldera Toba)}

\author{
The Linkage between Environmental Aspects in Sustainable Tourism and Distinctiveness \\ (Case Study of the Toba Caldera Geopark Area)
}

\author{
Nurlisa Gintinga,b, $\mathrm{c}^{*}$, Riris Adriaty Putri E S ${ }^{\mathrm{a}^{*}}$, Annisa Salsabilla $\mathrm{a}^{\mathrm{a}^{*}}$, Recrisa Lathersia ${ }^{\mathrm{a}^{*}}$,Putri Ayu \\ Dirgantara $Y^{a^{*}}$, Munazirah ${ }^{\mathrm{a}^{*}}$ \\ aProgram Studi Teknik Arsitektur, Fakultas Teknik, Universitas Sumatera Utara, Jalan Perpustakaan Gedung J7 Kampus USU, Medan, 20155, Indonesia \\ ${ }^{b}$ Kelompok Kerja Pariwisata Kawasan Danau Toba dan Pariwisata Berkelnajutan, Universitas Sumatera Utara, Jalan Dr. Mansyur Kampus USU, Medan, 20155, \\ Indonesia \\ ${ }^{c}$ Monitoring Centre for Sustainable Tourism Observatory (MCSTO) Universitas Sumatera Utara, Jalan Perpustakaan Gedung J7 Kampus USU, Medan, 20155, \\ Indonesia
}

nurlisa@usu.ac.id,priris02@gmail.com,lathersiarecrisa@gmail.com, tarafiaj@gmail.com, cut.aisyah714@gmail.com

\begin{abstract}
Abstrak
Aspek lingkungan merupakan salah satu hal yang sangat penting dalam perkembangan pariwisata berkelanjutan di kawasan Geopark Kaldera Toba. Hal ini dikarenakan yang menjadi nilai jual paling tinggi dari kawasan Geopark Kaldera Toba sendiri adalah lingkungannya. Dimana lingkungan kawasan Geopark Kaldera Toba memiliki berbagai kekhasan dan keunikan. Kekhasan dan keunikan tersebut berpotensi sebagai pariwisata berkelanjutan dan menciptakan lapangan pekerjaan baru bagi masyarakat di kawasan tersebut. Aspek lingkungan pada pariwisata berkelanjutan pada kawasan ini dapat dilihat dari aspek distinctiveness yang ada pada kawasan, khususnya Kecamatan Simanindo dan Kecamatan Pangururan. Aspek lingkungan memiliki empat variabel yaitulandscape, kualitas air, kualitas udara dan kebersihan kawasan. Faktor-faktor lingkungan adalah Landscape, kualitas udara, kualitas airdan kebersihan kawasan. Distinctiveness memiliki empat variabel yaitu landmark, keunikan, karakter tertentu dan perbedaan persepsi. Penelitian ini merupakan jenis penelitian desktiptif yang menggunakan metode campuran. Data yang digunakan merupakan hasil observasi, wawancara dan kuesioner pada warga lokal dan wisatawan. Berdasarkan penelitian ini dapat disimpulkan bahwa aspek lingkungan pariwisata berkelanjutan yang berdasarkan pada distinctiveness di kawasan Geopark Kaldera Toba khususnya Kecamatan Simanindo dan Pangururan memiliki pengaruh pada kualitas pengembangan objek wisata dikawasan tersebut.
\end{abstract}

Kata Kunci: Lingkungan, pariwisata berkelanjutan, distinctiveness

\begin{abstract}
The environmental aspect is one of the most important things in the development of sustainable tourism in the Toba Caldera Geopark region. This is because the highest selling point of the Toba Caldera Geopark area is its environment. Where the environment of the Toba Caldera Geopark region has a variety of uniqueness and uniqueness. This uniqueness and uniqueness has the potential as sustainable tourism and creates new jobs for the people in the region. The environmental aspects of sustainable tourism in this region can be seen from the distinctiveness aspects that exist in the region, specifically Simanindo District and Pangururan District. Environmental aspects have four variables namely landscape, water quality, air quality and regional cleanliness. Environmental factors are Landscape, air quality, water quality and regional cleanliness. Distinctiveness has four variables namely landmarks, uniqueness, certain characters and differences in perception. This research is a type of descriptive research that uses a mixed method. The data used are the results of observations, interviews and questionnaires with local residents and tourists. Based on this study it can be concluded that aspects of the sustainable tourism environment based on distinctiveness in the Toba Caldera Geopark region especially Simanindo and Pangururan Districts have an influence on the quality of the development of attractions in the region.
\end{abstract}

Keywords: Environment, sustainable tourism, distinctiveness

(C) 2020 The Authors. Published by TALENTA Publisher Universitas Sumatera Utara Selection and peer-review under responsibility of Seminar Nasional Kearifan Lokal V 2020 p-ISSN: 2654-7031, e-ISSN: 2654-704X, DOI: 10.32734/ee.v3i1.855 


\section{Pendahuluan}

Pariwisata adalah simbol yang membantu membangun dan menyampaikan rasa identitas nasional (Palmer, 1999) ${ }^{[1]}$. Pariwisata juga menjadi faktor penting dalam proses pembangunan identitas (Light, 2001)[2]. Selain memiliki kekhasan sebagai penambahan nilai kawasan, pariwisata juga dianggap sebagai metode yang efektif untuk mengurangi kemiskinan di beberapa komunitas tradisional (Croes, 2014) karena pariwisata menyediakan pekerjaan yang berbeda dari mata pencaharian tradisional (World Tourism Organization, 2002) serta peluang untuk menjual produk lokal (Lee, 2013; Lepp, 2007). Oleh sebab itu dapat di simpulkan bahwa pariwisata dan kekhasan lokal adalah dua hal yang saling berhubungan. Karena kekhasan lokal dapat menghidupkan pariwisata kawasan, sehingga kawasan tersebut akandi kunjungi oleh wisatawan.

Suatu tempat memiliki identitas ketika memiliki unsur kekhasan atau keunikan sehingga dapat dibedakan dari tempat lain di dunia (Twigger-ross dan Uzzell, 1996). Dalam hal ini, persepsi seseorang tentang keunikan harus positif (Paumier, 2004).Tempat dapat menjadi komponen yang membedakan satu orang dengan orang lain. Sejalan dengan konsep ini, kekhasan menyebabkan seseorang memiliki afiliasi khusus dengannya dan lingkungan yang jelas berbeda dari jenis afiliasi lainnya (Twigger-ross dan Uzzell, 1996). Sehingga dapat kita lihat bahwa kekhasan merupakan elemen penting yang dapat memberikan dampak positif dan berguna baik terhadap kawasannya dan juga masyarakatnya.Apabila sebuah kawasan tidak memiliki kekhasan atau karakter, maka kawasan ini akan terkesan membosankan dan mungkin saja dilupakan. Tetapi apabila sebuah kawasan menarik dan mudah dikenali, kekhasan atau karakteristik tertentu pada kawasan tersebut akan membedakannya dengan kawasan lain. Kekhasan atau karakteristik tertentu suatu kawasan dapat kita lihat dari aktivitas budaya yang terjadi, produk lokal, transportasi, dan bangunannya. Maka peneliti memutuskan untuk mengkaji aspek distinctiveness sebagai salah satu upaya dalam peningkatan pariwisata.

Pergeseran minat terhadap pariwisata terbukti dengan munculnya sustainable tourism, yang berfokus pada konservasi tujuan dan meningkatkan pengetahuan tentang dunia luar (Ceballos-Lascuráin, 1996; Williams dan Montanari 1999; Perez dan Sampol, 2000). Kemudian di antara berbagai bentuk pariwisata berkelanjutan, geowisata mungkin adalah yang terbaru dan yang dimilikinya segera menjadi fenomena global sejak kemunculannya di awal 2000-an (Stokes, Cook, dan Drew, 2003; Dowling, 2011).

Di Indonesia, Kaldera Toba adalah sebuah jejak geologi yang berasal dari hasil letusan gunungapi terbesar selama dua juta tahun terakhir. Geopark Kaldera Toba meliputi wilayah administratif 7 kabupaten di Provinsi Sumatera Utara salah satunya adalah Kabupaten Samosir. Kabupaten Samosir sendiri memiliki 9 kecamatan, dua diantaranya adalah Kecamatan Simanindo dan Kecamatan Pangururan yang dimana 2 kecamatan tersebut menjadi lokasi penelitian ini.Menurut Bupati Samosir, Rapidin Simbolon, berdasarkan data dari Dinas pariwisata, selama 2 hari libur perayaan kemerdekaan, tercatat ada 3.000 pengunjung di 21 objek wisata binaan PemKab.

Kecamatan Simanindo dan Kecamatan Pangururan kabupaten Samosir, merupakan destinasi wisata yang berpotensi sebagai parawisata berkelanjutan berbasis geopark, dikarenakan kawasan ini memiliki kondisi alam yang mendukung, selain itu kawasan ini juga kental akan warisan budaya dan sejarahnya. Di samping itu, pengembangan pariwisata berkelanjutan berbasis geopark juga dapat membantu peningkatan perekonomian masyarakat lokal. kawasan Simanindo dan Pangururan sebagai potensi pariwisata berkelanjutan berbasis geopark masih membutuhkan pengembangan pariwisata yang menekankan pada aspek lingkungan pada distinctiveness kawasan. Untuk itu maka perlu dilakukan pemetaan aspek distinctivenesspada kawasan guna memudahkan pengembangan pariwisata berkelanjutan. Untuk menemukan distinctiveness tersebut diperlukan kajian terhadap aspek-aspek distinctiveness itu sendiri, sehingga muncul permasalahan yang menjadi objek penelitian, yaitu Bagaimana pariwisata berkelanjutan di kawasan wisata Simanindo dan Pangururan Kabupaten Samosir berdasarkan elemen-elemen aspek lingkungan dan distinctiveness sertabagaimana pengaruh aspek lingkungan pariwisata berkelanjutan padadistinctiveness kawasan wisata Simanindo dan Pangururan Kabupaten Samosir. Tujuan penelitian ini sendiri adalah untuk menemukan serta pemetaan lokasi-lokasi yang memiliki aspek distinctiveness di kawasan wisata Simanindo dan Pangururan Kabupaten Samosir untuk pengembangan pariwisata berkelanjutan berbasis geopark.

\section{Distinctiveness}

Berdasarkan prinsip distinctiveness, Wang dan Xu (2015) memperkirakan bahwa penghuni yang tinggal di tempat yang berbeda (secara fisik atau budaya), relatif dibandingkan dengan tempat lain yang sebanding dengan yang sekarang, akan menunjukkan lebih banyak identifikasi tempat. Kekhasannya juga berkontribusi pada penambahan nilai atau kesan wisatawan terhadap tempat tersebut (Tussyadiah, 2014).Oleh karena itu, dapat kita lihat bahwa karakteristik suatu tempat berkaitan erat dengan konteks sosial. Selain itu, karakteristik suatu tempat dapatmemudahkan dalam membedakan satu tempat dengan tempat lainnya. Aspek-aspek distinctiveness yang akandigunakan dapat dilihat dalam bentuk tabel berikut. 
Tabel 1. Kesimpulan Aspek-aspek Distinctiveness

\begin{tabular}{ll}
\hline \multicolumn{1}{c}{ Item } & \multicolumn{1}{c}{ Kesimpulan } \\
\hline Landmark & $\begin{array}{l}\text { Merupakan objek yang memiliki visual menonjol dan berperan besar } \\
\text { dalam mempromosikan kawasan tersebut. Dapat berupa bangunan seperti } \\
\text { tugu ataupun pengunangan dan air terjun. }\end{array}$ \\
\hline Keunikan & $\begin{array}{l}\text { Merupakan kekhasan yang dimiliki suatu kawasan. Dapat berupa aktivitas } \\
\text { budaya yang dapat dirasakan baik bagi warga lokal maupun wisatawan. }\end{array}$ \\
\hline Karakter Tertentu & $\begin{array}{l}\text { Merupakan karakteristik khusus yang dimiliki kawasan tersebut dan } \\
\text { berbeda dengan kawasan lain. Dapat berupa bangunan tradisional. }\end{array}$ \\
\hline Perbedaan Persepsi & $\begin{array}{l}\text { Merupakan sudut pandang wisatawan dan masyarakat lokal terhadap titi- } \\
\text { titik wisata yang terdapat pada kawasan. }\end{array}$ \\
\hline
\end{tabular}

\subsection{Aspek Lingkungan Pengembangan Pariwisata Berkelanjutan}

Dalam hal ini pengembangan pariwisata berkelanjutan berdasarkan aspek Lingkungan memiliki beberapa indikator penilaian, dimana indikator tersebut mencerminkan kontribusi pengembangan pariwisata berkelanjutan terhadap lingkungan kawasan wisata.MenurutAnna Spenceley, (2005),ada beberapa indikator penilaian terhadap aspek lingkungan pariwisata berkelanjutan yaitu 1) Landscape, Hal ini berkaitan dengan apa saja faktor-faktor lingkun gan alami yang tersedia pada kawasan; 2) Kualitas Udara, Destinasi wisata harusnya dapat memiliki kualitas udara yang baik dan tidak berdampak buruk bagi wisatawan (tidak berpolusi); 3) Kualitas Air, Destinasi wisata sudah seharusnnya memiliki aliran dan supply air yang baik sehingga dapat di manfaatkan oleh warga sekitar dan juga wisatawan. Indikator aspek lingkungan juga pernah diteliti oleh Tanja Mihalic (2000), dimana ia menyimpulkan bahwa indikator-indikator aspek lingkungan pariwisata berkelanjutan terdiri dari 1) Kualitas udara, Kualitas udara kawasan dapat menjadi salah satu indikator yang mempengaruhi tingkat kennyamanan wisatawan ;2) Kualitas air, Kualitas air yang baik dan memadai dapat berguna bagi kepentingan lokal dan juga wisatawan (seperti mandi, minum, dll) ; 3) Tingkat kebisingan, Persentase kebisingan suatu kawasan dapat di pengaruhi oleh banyaknya kendaraan atau mungkin aktivitas yang padat ;4) Kebersihan kawasan.

Tabel 2. Kesimpulan indikator-indikator aspek lingkungan pengembangan pariwisata berkelanjutan

\begin{tabular}{ll}
\hline \multicolumn{1}{c}{ Item } & \multicolumn{1}{c}{ Kesimpulan } \\
\hline Landscape & $\begin{array}{l}\text { Pemandangan dan faktor alamiah lainnya yang tersedia pada tiap-tiap } \\
\text { kawasan adalah faktor utama yang dapat menonjolkan kawasan tersebut. }\end{array}$
\end{tabular}

\begin{tabular}{ll}
\hline Kualitas air & $\begin{array}{l}\text { Kualitas air yang bersih dan penyaluran air yang baik ke seluruh kawasan } \\
\text { dapat menunjang kemajuan pengembangan pariwisata kawasan. }\end{array}$ \\
\hline Kualitas udara & $\begin{array}{l}\text { Udara yang tersedia pada kawasan wisata sudah seharusnya terjaga dengan } \\
\text { baik dan jauh dari polusi. }\end{array}$ \\
\hline Kebersihan kawasan & $\begin{array}{l}\text { Kebersihan kawasan adalah salah satu faktor penting yang selain } \\
\text { menunjang nilai pariwisata namun juga sangat membantu dalam menjaga } \\
\text { kawasan tersebut kedepannya. }\end{array}$ \\
\hline
\end{tabular}

\section{Metodologi}

Berdasarkan kajian yang telah dilakukan sebelumnya jenis penelitian yang tepat diterapkan pada kajian ini adalah penelitian deskriptif dengan caracampuran. Kajian keterkaitan antara aspek lingkungan pada pariwisata berkelanjutan terhadap distinctivenessini hanya dilakukan analisa data sampai pada tahap dimana variabel dideskripsikan satu persatu secara sistematik dan faktual (Hadeli, 2006;11).Metoda campuran digunakan dengan cara pengumpulan data primer dalam bentuk kualitatif (observasi dan wawancara) dan kuantitatif (kuesioner wisatawan dan warga lokal). Metoda ini dilakukan untuk memperoleh data yang lebih komprehensif, objektif, valid dan reliable. Dalam menentukan lokasi penelitian ada beberapa hal yang menjadi pertimbangan peneliti. Diantaranya adalah apakah lokasi-lokasi tersebut memiliki aspek-aspek distinctiveness yang nantinya akan dimanfaatkan untuk mengembangkan pariwisata berkelanjutan berbasis geopark. Aspek-aspek distinctiveness tersebut adalah landmark, keunikan, karakter tertentu, dan perbedaan persepsi. Pemilihan lokasi juga didasari pada tingkat kunjungan wisatawan tertinggi yaitu 5 titik pada Kecamatan Simanindo dan 5 titik pada Kecamatan Pangururan. 

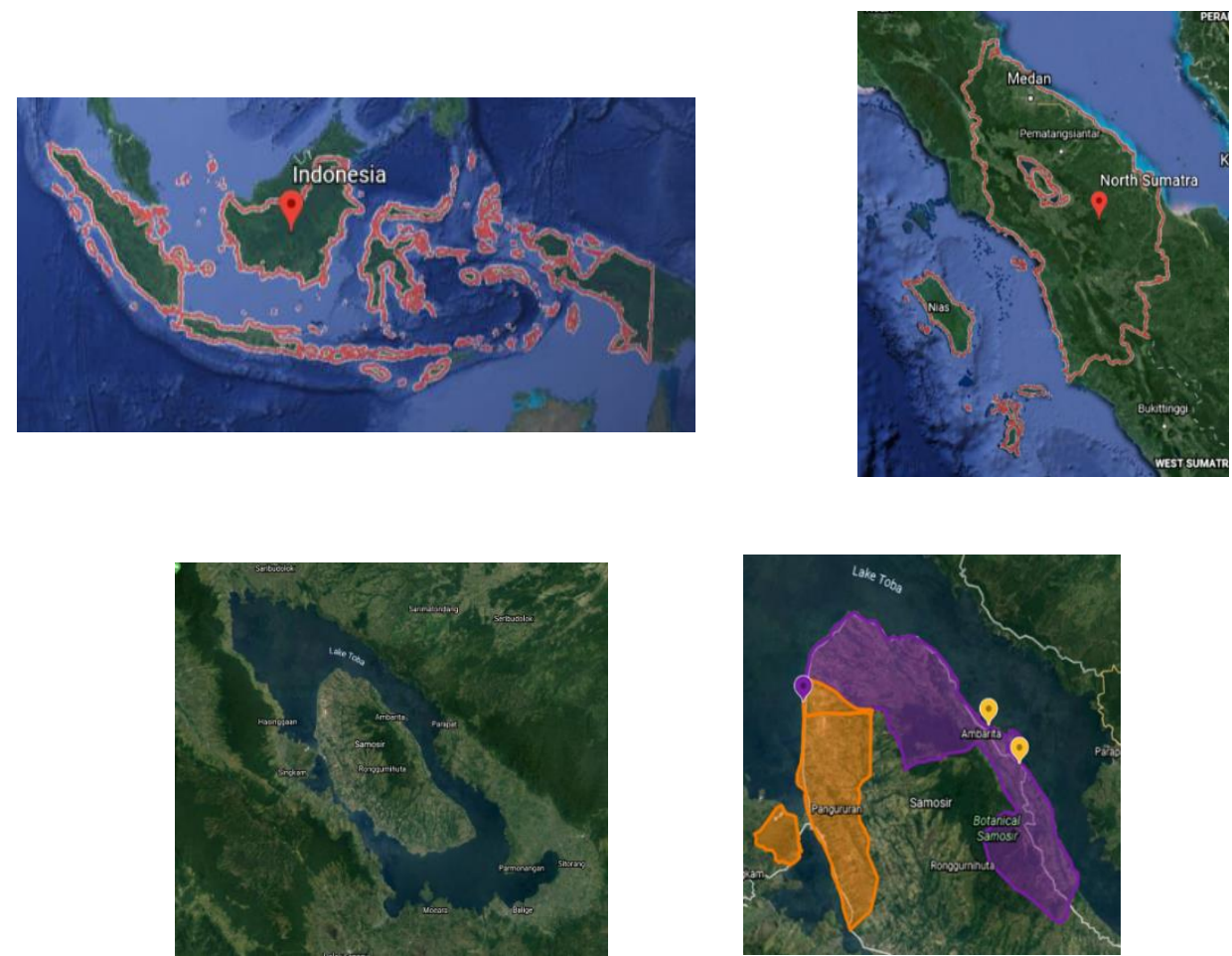

Gambar 1. Lokasi Penelitian di kawasan Geopark Kaldera Toba Kecamatan Pangururan dan Kecamatan Simanindo

Dalam penentuan variabel indikator yang digunakan pada tiap variabel adalah interpretasi terhadap indikator-indikator yang berasal dari telaah pustaka yang telah dilakukan sebelumnya. Maka berdasarkan itu, penelitian ini terdiri dari dua kelompok variabel, yaitu (1) variabel aspek lingkungan pengembangan pariwisata berkelanjutan (tabel 2) dan (2) variabel aspek distinctiveness(tabel 1).Adapun indikator-indikator yang terdapat pada variabel pertama dan variabel kedua ditentukan berdasarkan parameter-parameter yang terdapat pada kajian pustaka yang telah di interpretasi oleh peneliti (table 1 dan tabel 2). Variabel-variabel yang telah dipilih akan menjadi dasar dalam mnciptakan variabel penelitian.

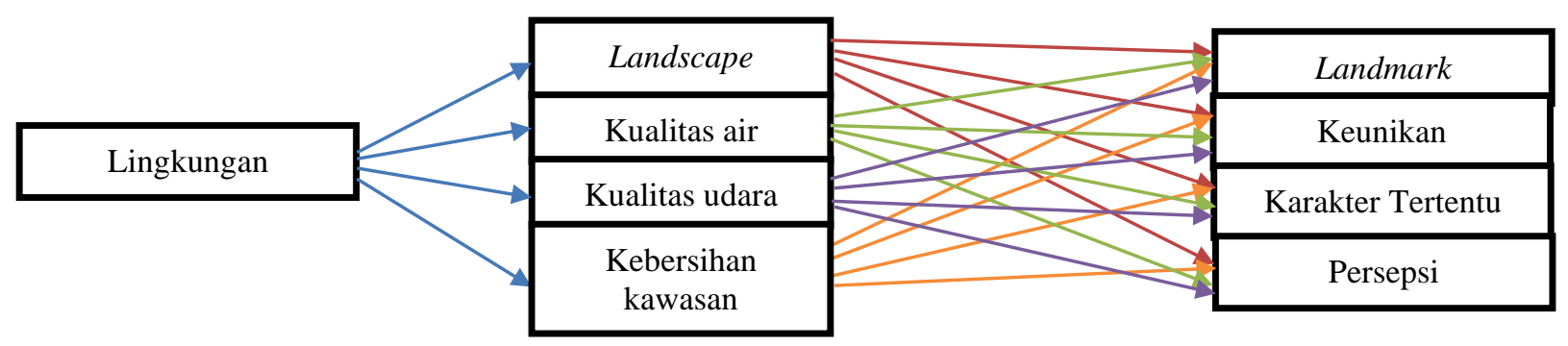

Gambar 4. Diagram kajian aspek lingkungan terhadap distinctiveness

\subsection{Kajian Lingkungan Pariwisata Berkelanjutan Berdasarkan Aspek Distinctiveness}

Aspek lingkungan dikaji dengan pertimbangan penggunaan sumber daya alam yang menjadi faktorbutama pengembangan pariwisata yang tetap disertai dengan usaha-usaha pelestarian lingkungan yang melindungi keragaman aspek lingkungan dimensi (Wiwattan dan To-im, 2014). Tiga indikator penilaian aspek lingkungan pariwisata berkelanjutan yaitu 1) Landscape, Hal ini berkaitan dengan faktor-faktor lingkungan alami yang ada pada kawasan; 2) Kualitas Udara, Destinasi wisata harusnya tidak berdampak buruk bagi wisatawan (tidak berpolusi); 3) Kualitas Air, Destinasi wisata memiliki sumber dan aliran yang baik untuk dapat di manfaatkan warga sekitar dan juga wisatawan (Anna Spenceley, 2005). 
Di kawasan Geopark Kaldera Toba faktor lingkungan merupakan faktor yang sangat berpengaruh dalam perkembangan pariwisata berkelanjutan. Ini dikarenakan kawasan Geopark Kaldera Toba memiliki alam yang hijau dan asri.Hal ini juga yang membedakan kawasan Geopark Kaldera Toba dengan kawasan wisata lainnya. Dengan adanya perbedaan ini, dapat ditemukan distinctiveness pada kawasan Geopark Kaldera Toba yang dapat mendukung pariwisata berkelanjutan pada kawasan ini kedepannya. Untuk melihatn dan menemukan aspek lingkungan pariwisata berkelanjutan berdasarkan distinctiveness, dilakukan pengumpulan data terhadap persepsi wisatawan dan masyarakat lokal dengan metoda kuisoner. Persepsi wisatawan terhadap aspek lingkungan pariwisata berkelanjutan berdasarkan distinctiveness di dua kecamatan yaitu Simanindo dan Pangururan yang berada di Kaldera Toba dapat dilihat pada (tabel 4).

Tabel 3. Kajian Lingkungan Pariwisata Berkelanjutan Berdasarkan Aspek Distinctiveness (Wisatawan)

\begin{tabular}{|c|c|c|c|c|c|c|c|c|}
\hline \multirow[t]{2}{*}{ Kode } & \multirow[t]{2}{*}{ Pernyataan } & \multicolumn{2}{|c|}{ Simanindo } & \multirow[t]{2}{*}{ Mean } & \multicolumn{2}{|c|}{ Pangururan } & \multirow[t]{2}{*}{ Mean } & \multirow{2}{*}{$\begin{array}{l}\text { Total } \\
\text { mean }\end{array}$} \\
\hline & & Wisnus & Wisman & & Wisnus & Wisman & & \\
\hline LL2 & $\begin{array}{l}\text { Saya merasa daerah landmark } \\
\text { dan sekitarnya terjaga } \\
\text { kebersihannya. }\end{array}$ & 3,74 & 3,4 & 3,57 & 3,58 & 4,2 & 3,8 & 3,69 \\
\hline LT2 & $\begin{array}{l}\text { Bangunan atau rumah adat yang } \\
\text { ada terawat dan tidak kotor. }\end{array}$ & 3,6 & 3,8 & 3,7 & 3,86 & 4 & 3,9 & 3,8 \\
\hline LP1 & $\begin{array}{l}\text { Pemandangan alam sekitar } \\
\text { sangat menarik untuk } \\
\text { diabadikan. }\end{array}$ & 4,66 & 4,7 & 4,68 & 4,15 & 4,8 & 4,5 & 4,59 \\
\hline LP2 & $\begin{array}{l}\text { Mudah menemukan air bersih di } \\
\text { tempat wisata. }\end{array}$ & 3,86 & 4,1 & 3,98 & 4,24 & 4,4 & 4,3 & 4,14 \\
\hline LP3 & $\begin{array}{l}\text { Keadaan udara baik dan tidak } \\
\text { tercemar oleh polusi. }\end{array}$ & 4,48 & 4,4 & 4,44 & 4.07 & 4,6 & 4,3 & 4,37 \\
\hline LP4 & $\begin{array}{l}\text { Tempat wisata dalam keadaan } \\
\text { bersih dan tidak kotor oleh } \\
\text { sampah. }\end{array}$ & 3,9 & 3,6 & 3,75 & 3,61 & 3,9 & 3,7 & 3,73 \\
\hline
\end{tabular}

Kemudian untuk persepsi warga lokal terhadap aspek lingkungan pariwisata berkelanjutan berdasarkan distinctiveness di dua kecamatan yaitu Simanindo dan Pangururan yang berada di Kaldera Toba dapat dilihat pada (tabel 5).

Tabel 5 . Kajian Lingkungan Pariwisata Berkelanjutan Berdasarkan Aspek Distinctiveness (Warga Lokal)

\begin{tabular}{lllcc}
\hline Kode & Pernyataan & Simanindo & Pangururan & Total mean \\
\hline LP2 & $\begin{array}{l}\text { Mudah mendapatkan air bersih di lingkungan } \\
\text { sekitar. }\end{array}$ & 4.42 & 4.6 & 4.51 \\
\hline LP3 & $\begin{array}{l}\text { Udara pada lingkungan sekitar tidak tercemar } \\
\text { oleh polusi. }\end{array}$ & 4.52 & 4.72 & 4.62 \\
\hline
\end{tabular}

Analisa aspek lingkungan pariwisata berkelanjutan berdasarkan distinctiveness di Kecamatan Simanindo dan Pangururan dapat dibagi berdasarkan empat sub-aspek yaitu (1) Aspek lingkungan berdasarkan landmark; (2) Aspek lingkungan berdasarkan keunikan; (3) Aspek lingkungan berdasarkan karakter tertentu; dan (4) Aspek lingkungan berdasarkan persepsi. Hasil analisa dilakukan melalui pembahasan kondisi fakta yang didapatkan di kedua Kecamatan tersebut laluakan dibandingkan dan juga dikaitkan kembali dengan kajian teori yang telah dilakukan di bab sebelumnya.

\subsection{Aspek Lingkungan Berdasarkan Landmark}

Di Pangururan dapat kita lihat bahwa tempat yang menjadi landmark adalah kawasan wisata Pantai Pasir Putih Parbaba. Pantai Pasir Putih sendiri merupakan salah satu tempat wisata di pangururan yang tidak sepi pengunjung di hari-hari libur nasional danweekend. Pantai Pasir Putih memiliki kondisi pantai yang cukup terjaga kebersihannya, sampah-sampah biasanya dikumpul dikios di sepanjang garis pantai. Hal ini dapat kita lihat dari hasil tabel yang menunjukkan rata-rata tingkat kenyamanan wisatawan terhadap kebersihan kawasan dengan nilai 3,69 yang artinya cukup. Selain itu di pesisir pantai ini juga dipenuhi oleh pohon-pohon rindang. Pemandangan yang ditawarkan sebagai view dari arah pantai adalah adalah Gunung Pusuk Buhit. View ini dapat menjadi objek fotografi yang bagus. Letak pantai juga mudah di akses sehingga tidak sulit untuk menemukannya. 


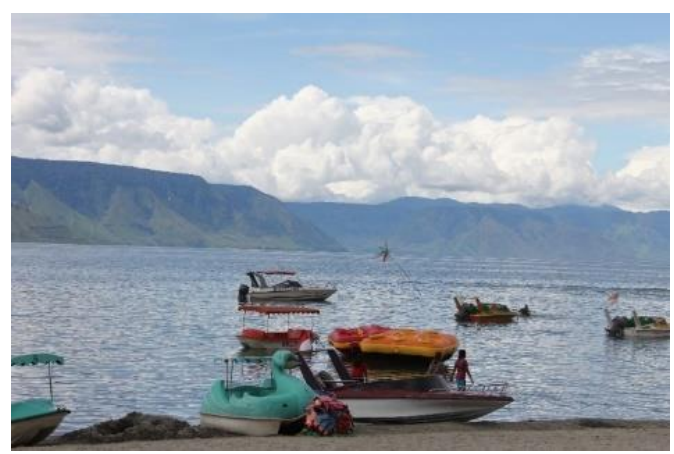

Gambar 5. Pantai Pasir Putih sebagai Landmark Kecamatan Pangururan

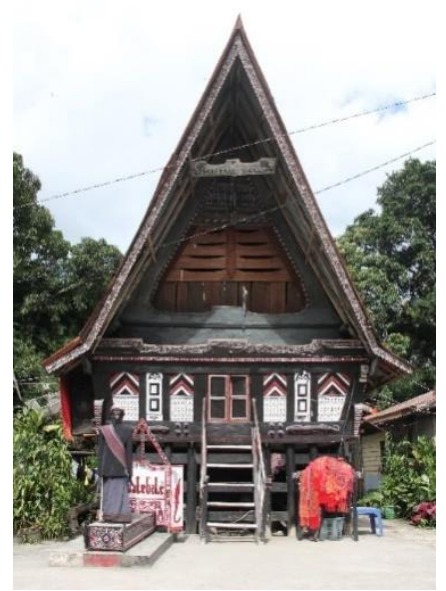

Gambar 6. Boneka Sigale- gale sebagai salah satu atraksi utama di Tomok

Pada Kecamatan Simanindo terdapat patung Sigale-gale yang terletak di desa Tomok. Patung ini sudah terkenal sejak lama dan kerap menarik perhatian wisatawan-wisatawan yang datang ke desa Tomok. Letak boneka Sigale-gale ini berada di atas bukit, dengan akses jalan yang dapat di tempuh melalui kios-kios souvenir yang ada di desa Tomok. Kondisi jalan menuju objek wisata ini sendiri menanjak karena faktor kontur tanah. Kawasan boneka Sigale-gale dan desa Tomok sendiri cukup terjaga kebersihannya, hal ini di dukung dengan hasil rata-rata tingkat kenyamanan wisatawan terhadap kebersihan kawasan yang mencapai nilai 3,69 yang artinya berada pada rentang "cukup".

Selain dari keunikan ataupun karakteristik tertentu, landmark juga berkontribusi dalam menciptakan distinctiveness. Landmark adalah salah satu kunci elemen pembentuk image dan identitas lingkungan pariwisata (Hussain dan Ujang, 2014). Landmark dapat berupa beragam macam bentuk, mulai dari tugu, rumah adat, candi, dll. Dalam Penelitian kali ini terdapat masing-masing landmark yang dapat menjadi penanda dan pembeda di dua kecamatan penelitian (Simanindo dan Pangururan).

\subsection{Aspek Lingkungan Berdasarkan Keunikan}

Keunikan sebuah tempat dapat membantu seseorang untuk mngeorientasikan tempat tersebut dan memberikan kenyamanan sehingga orang-orang dapat merasa terhubung dengan tempat tersebut. Maka dari itu, karakter-karakter tempat yang berbedalah yang memunculkan keunikan itu sendiri (Ginting dkk, 2017). Keunikan dapat berupa banyak hal, salah satu yg menonjol adalah kebudayaan asli/lokal pada kawasan yang di teliti. Pada awalnya baik Kecamatan Simanindo maupun Pangururan keduanya memiliki kebudayaan lokal yang tidak jauh berbeda, yaitu bertani dan berkebun (ladang). Kebudayaan ini muncul dari pengaruh kondisi alam sekitar yang dipenuhi oleh ruang hijau yang dapat dimanfaatkan oleh warga sekitar dengan mudahnya. Hal ini juga di sampaikan oleh narasumber.

... "kalau warga sekitar ini sebenarnya dari awal memang mengandalkan bertani dan berladang, karena kita fokus awalnya adalah agriculture maka dari itu hingga saat ini daerah samosir ini masih di penuhi oleh lahan-lahan hijau yang masih terjaga"... (Narasumber : Robintang Naibaho, Kepala Bidang Pengendalian, Dinas Priwisata Samosir) 

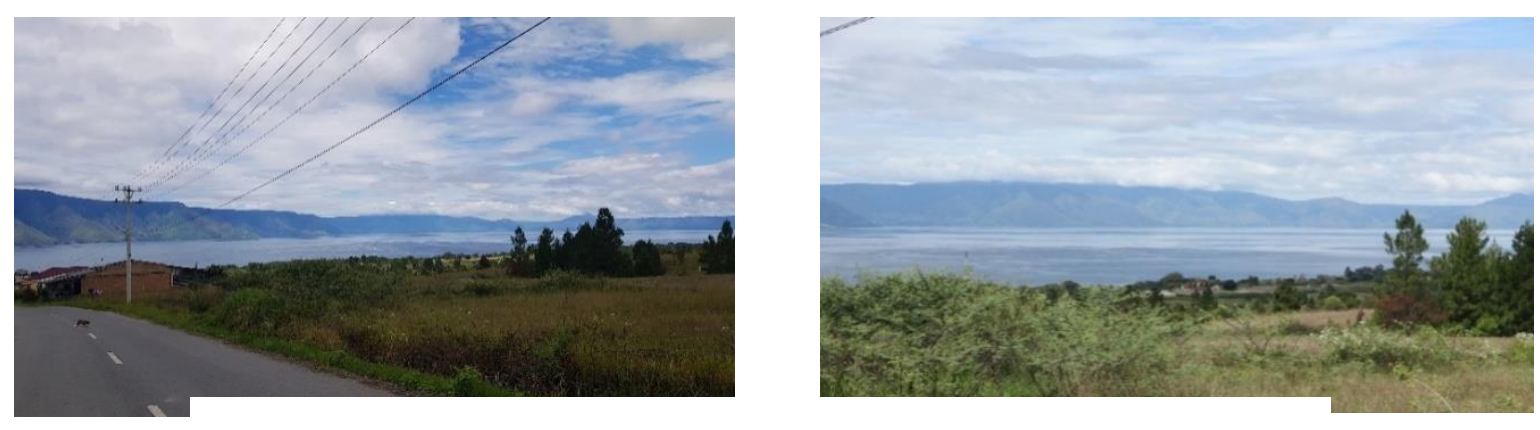

Gambar 7. Lahan-lahan hijau di Kecamatan Pangururan dan Simanindo

Kemudian di samping itu juga terdapat nilai-nilai budayaan etnis dari masyarakat batak yang masih kental hingga saat ini di kedua Kecamatan tersebut seperti peninggalan-peninggalan masih di jaga dan di lestarikan oleh warga lokal. Selain itu yang menjadi keunikan kawasan ini juga dapat dilihat dari bentuk dan jenis souvenir yang dijual oleh masyarakat.

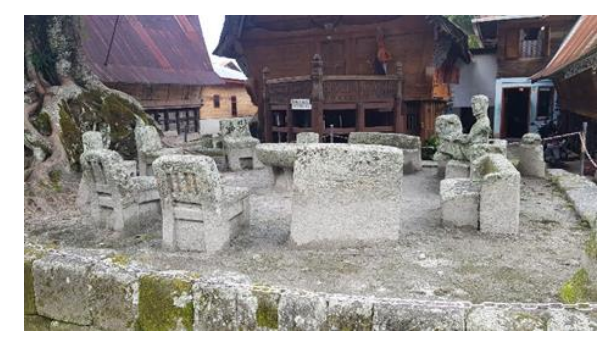

Gambar 8. Peninggalan budaya Batak

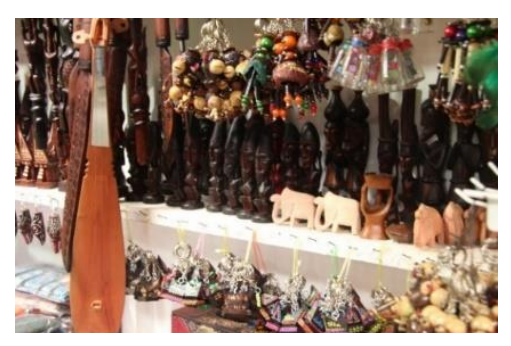

Gambar 9. Peninggalan budaya Batak

Dalam kajian ini, Pangururan dan Simanindo memiliki kebudayaan yang tidak jauh berbeda, mengingat etnis lokal yang ada samasama berasal dari etnis Batak. Begitu pula dengan budaya bertani/berladang yang masih mereka jalani hingga saat ini. Hal ini tentu saja semakin memberi dampak positif pada kawasan Kaldera Toba sebagai sektor pariwisata alam.

\subsection{Aspek Lingkungan Berdasarkan Karakter Tertentu}

Pada kedua kecamatan ini cukup mudah dan banyak ditemui bangunan tradisional yg masih berdiri kokoh. Bangunan tradisonal ini juga sudah berdiri sejak lama dengan didasari oleh filosofi dan kepercayaan masyarakat batak toba hingga saat ini. Hal ini juga diperkuat oleh pernyataan narasumber.

"bangunan rumah adat ini kan sudah ada sejak lama, sejarahnya panjang, jadi saya rasa sudah sewajarnya lah di pelihara dan di rawat agar tidak hilang nilai-nilai sejarah bataknya" (Narasumber: Riris, Stakeholder museum Huta Bolon)

Bangunan-bangunan tradisional atau rumah adat ini juga menjadi salah satu atraksi wisata yang dapat di nikmati oleh para wisatawan. Maka dari itu kelestarian dan kebersihan bangunan adat yang ada di kedua kecamatan ini (Simanindo dan Pangururan) tetap dijaga baik oleh warga sekitar maupun para stakeholder yang bersangkutan.Hal ini sesuai dengan data yang tertera pada hasil penyebaran kuisoner di kedua kecamatan (Simanindo dan Pangururan) pada tabel 4 baik terhadap Wisatawan Lokal maupun 
Wisatawan Asing, keduanya setuju (dengan hasil rata-rata 3,8 yang mana tergolong dalam kategori "cukup") bahwa rumah-rumah adat yang ada masih terjaga kebersihannya sehingga menarik minat para wisatawan.
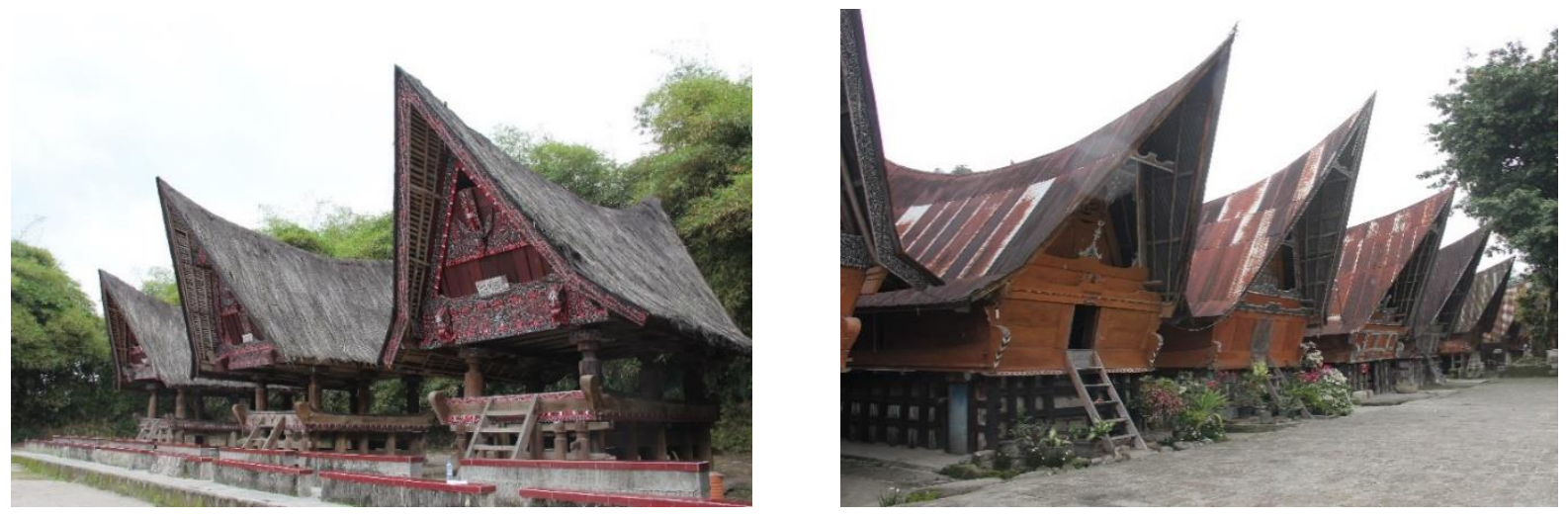

Gambar 10. Bangunan Tradisional

Seperti yang telah dijabarkan di atas, maka dapat kita lihat bahwa karakter tertentu sebuah kawasan dapat berbentuk rumah adat dengan kekhasan budayanya. Rumah adat di Pangururan dan Simanindo, keduanya masih banyakyang dapatdijumpai di sepanjang jalan di Samosir. Selain itu juga rumah-rumah adat ini juga sudah banyak yang di konservasi untuk menjaga ketahanan dan umur bangunan tersebut baik melalui pemerintahan maupun secara pribadi (swasta). Rumah-rumah adat ini juga dapat menjadi salah satu wisata budaya yang di nikmati oleh wisatawan. Oleh karena itu rumah adat di kedua kecamatan ini masih terawat hingga saat ini.

\subsection{Aspek Lingkungan Berdasarkan Persepsi}

Persepsi wisatawan dan masyarakat lokal juga penting untuk suatu objek wisata. Seperti yang terlihat pada tabel 4 bahwa baik wisatawan lokal maupun wisatawan asing keduanya bernilai total rata-rata hingga 4,59. Yang mana masuk kedalam kategori "baik" terhadap pendapat mereka mengenai pemandangan alam pada kedua kecamatan Penelitian (Simanindo dan Pangururan). Kemudian dapat dilihat juga pandangan wisatawan terhadap kualitas air dan kualitas udara di masing-masing kecamatan (simanindo dan pangururan). Wisatawan setuju bahwa kualitas air dan udara disetiap kecamatan sudah tergolong kedalam kategori "baik" (dengan nilai rata-rata 4,14 untuk kualitas air dan 4,37 untuk kualitas udara). Kemudian apabila dibandingkan dengan hasil rata-rata tingkat kebersihan dan kualitas air menurut masyarakat lokal maka masyarakat lokal menganggap bahwa daerah kawasan mereka sudah lebih dari cukup dalam hal ketersediaan air bersih dan juga kebersihan kawasannya. Hal ini dapat kita lihat pada tabel 5 dengan nilai ratarata total mencapai 4,51 untuk ketersediaan air bersih, yang artinya "baik" dan 4,62 untuk kualitas udara.

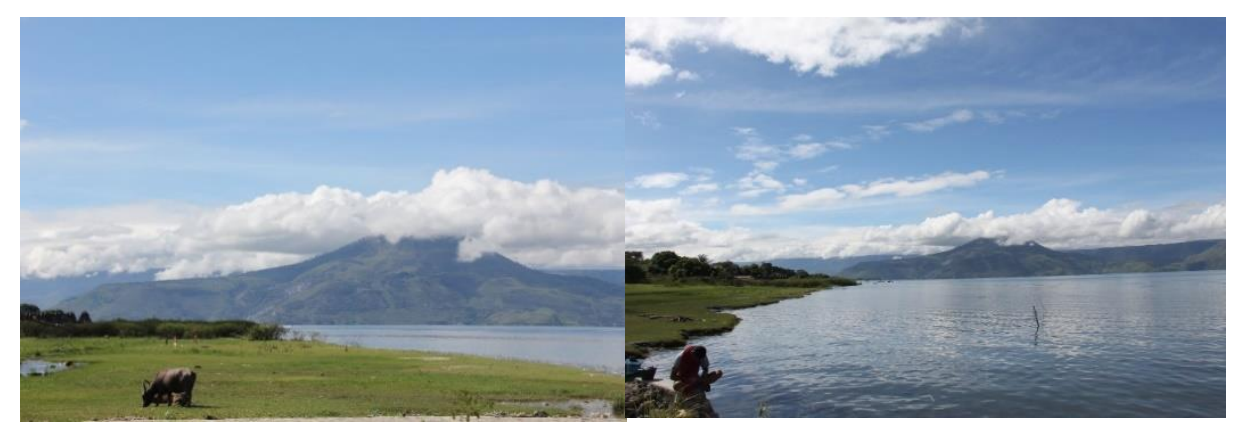

Gambar 11. Pemandangan lingkungan alam Kecamatan Pangururan dan Simanindo

Selanjutnya dapat disimpulkan berdasarkan tabel kuisoner Wisatawan bahwa baik pada kecamatan Simanindo maupun Pangururan keduanya sudah cukup dalam hal menjaga kebersihan lingkungan dan kebersihan kawasannya. Terlihat pada tabel total rata-rata kebersihan kawasan menurut wisatawan berada pada angka 3,73yang mana artinya sudah "cukup". 


\section{Kesimpulan}

Aspek lingkungan mempunyai pengaruh besar terhadap pariwisata berkelanjutan pada distinctiveness yang ada diwilayah kajian. Dimana kebersihan objek wisata, kondisi landscape, dan kualitas air serta udara pada kawasan kajian dapat mendukung keberlanjutan pariwisatanya. Pada landmark-landmark kawasan kajian sendiri, wisatawan maupun warga lokal berada dalam rentang cukup nyaman dan membantu wisatawan dalam mengenali objek wisata. Budaya dan buah tangan pada masing-masing objek wisata pun tidak terlalu berbeda dikarenakan etnis yang ada di lokasi adalah etnis batak. Bangunan-bangunan rumah adat batak pun masih banyak dijumpai disekitaran jalan menuju masing-masing objek wisata. Bangunan rumah adat ini di rawat dan dilestarikan oleh pemerintah, swasta maupun warga lokal. Penelitian ini diharapkan dapat memberikan manfaat yang baik untuk dapat diaplikasikan sebagai upaya pengembangan pariwisata berkelanjutan di kawasan geopark, Simanindo dan Pangururan

Kabupaten Samosir. Termasuk dapat membantuk bagi pemerintah, stakeholder, bidang akademik dan khususnya bagi masyarakat lokal dalam berbagai aspek pengembangan pariwisata berkelanjutan di kawasan Kecamatan Simanindo dan Pangururan. Selain kajian terhadap aspek lingkungan di wilayah ini, diharapkan juga kajian aspek lingkungan dapat di kaji lagi beberapa tahun kedepan dan di objek wisata lainnya.

\section{Referensi}

[1] Filippini, Massimo, and Lester C. Hunt. (2011) "Energy demand and energy efficiency in the OECD countries: a stochastic demand frontier approach." Energy Journal32 (2): 59-80.

[2] Filippini, Massimo, and Lester C. Hunt. (2012) "US residential energy demand and energy efficiency: A stochastic demand frontierapproach." Energy Economics34 (5): 1484-1491.

[3] Weyman-Jones, Thomas, Jùlia Mendonça Boucinha, and Catarina Feteira Inàcio. (2015) "Measuring electric energy efficiency in Portuguese households: a tool for energy policy." Management of Environmental Quality: An International Journal26 (3): 407-422.

[4] Saunders, Harry (2009) "Theoretical Foundations of the Rebound Effect”, in Joanne Evans and Lester Hunt (eds) International Handbook on the Economics of Energy, Cheltenham, Edward Elgar

[5] Sorrell, Steve (2009) “The Rebound Effect: definition and estimation”, in Joanne Evans and Lester Hunt (eds) International Handbook on the Economics of Energy, Cheltenham 